有明海のアサリの幼生加入過程と漁場形成

\title{
Larval Recruitment of the Clam Ruditapes philippinarum in Ariake Sound, Southern Japan
}

\author{
石井 亮・関口秀夫* \\ 三重大学生物資源学部 \\ 514-8507 津市上浜町 1515
}

Ryo ISHII and Hideo SEKIGUCHI*

Faculty of Bioresources, Mie University, Tsu, Mie 514-8507, Japan

\begin{abstract}
In 1987, the annual catch yields of the clam Ruditapes philippinarum in Japan reached their peak, ca. 140-160 thousand tons. The yields have drastically decreased since then, down to $25 \%$ of the peak after that period. This decrease was mainly due to decrease of the yields from Ariake Sound in Kumamoto Prefecture, southern Japan, which reached a peak (ca. 65 thousand tons) in 1977 and then drastically decreased, down to ca. $1 \%$ of the peak recently. In order to reveal the factors causing the catch depletion from 1977 onward in Kumamoto and from 1987 onward in Japan, we have studied patterns of larval recruitment of this species on tidal flats in Kumamoto. Frequent sampling was done for the different life stages of the clam (planktonic larvae, new settlers, juveniles, and adults), and cohort analyses were made using size frequency distributions. Our results indicate that larval supply may play critical role in structuring the age distribution and in either maintaining or inducing fluctuations in the benthic populations of the clam in Ariake Sound. This differs greatly from the our another study on tidal flats in Ise Bay along the Pacific coast of central Japan. Our studies in Ariake Sound strongly suggest that the drastic decrease in yields in the Sound may have been caused by a shortage of larval supply in addition to a decrease in size of the spawning stock and an increase in larval mortality resulting from environmental deterioration.
\end{abstract}

Key Words: Ruditapes philippinarum, larval recruitment, population dynamics, Ariake Sound

\section{1. 本邦のアサリ漁獲量の激減}

\section{1-1. 本邦のアサリ総漁獲量の激減}

Fig. 1 は本邦のアサリの年間総漁獲量と主要な数県の年 間漁獲量の変遷を示している。この図からも明らかなよう に，1975 年から 1987 年にかけて，14万-16万トンあった 総漁獲量が1987 年を境に激減し，2000 年にはほぼその 25\%の 4 万トン前後にまで落ち込んでいる。アサリ漁獲量 の多い県は, 1980 年代半ばまでは, 熊本県, 千葉県, 福 岡県と大分県の 4 県であったが, これ以降では, 愛知県, 千葉県, 三重県と熊本県の 4 県に変わっている.

熊本県や千葉県のアサリの漁獲量の激減が，1970 年代後 半にすでに始まっていたにもかかわらず，1980 年代初めの 福岡県の漁獲量の突発的な急増とそれに続く激減, 1980 年 代半ばの大分県の漁獲量の急増があったために, 1987 年ま

Received 20 Dec. 2001 Accepted 11 Apr. 2002

*: Corresponding author
では本邦のアサリの総漁獲量は 14 万-16万トンの横ばい 状態となっていた (Fig. 1). しかし，1987 年を境に，これ らの主要な県の漁獲量がいずれも減少し,アサリの総漁獲 量は激減を始めた。これらの主要な県の中でも，熊本県の 漁獲量の減少はとくに顕著であり，1977年に6万5千トン 近くあった漁獲量が，それは本邦の総漁獲量の約半分を占 めたが，2000 年前後にはほぼその1\%の漁獲量にまで落ち 込んでいる (Fig. 1).

本邦の沿岸・内湾水域のいたるところにおいて，そして そこはアサリの主要な生息域であるが，富栄息化の進行， 開発に伴う干拓面積の増大や干潟面積の減少といった人為 的な環境破壊が進んでいる。「近年における本邦のアサリ の総漁獲量の激減は, このような環境破壊に伴うアサリの 生息域の縮小と関係がある」との指摘もある。確かに，環 境破壊に伴うアサリの生息域の縮小は主要な沿岸・内湾水 域の漁獲量の減少に直接結びついており，それは特に東京 湾に扔いて顕著である。しかし，Fig. 1 を見る限り，事は そう簡単ではなさそうである。少なくとも Fig. 1 に基づけ ば, 1987 年以降の本邦のアサリの総漁獲量の激減は, 熊本 


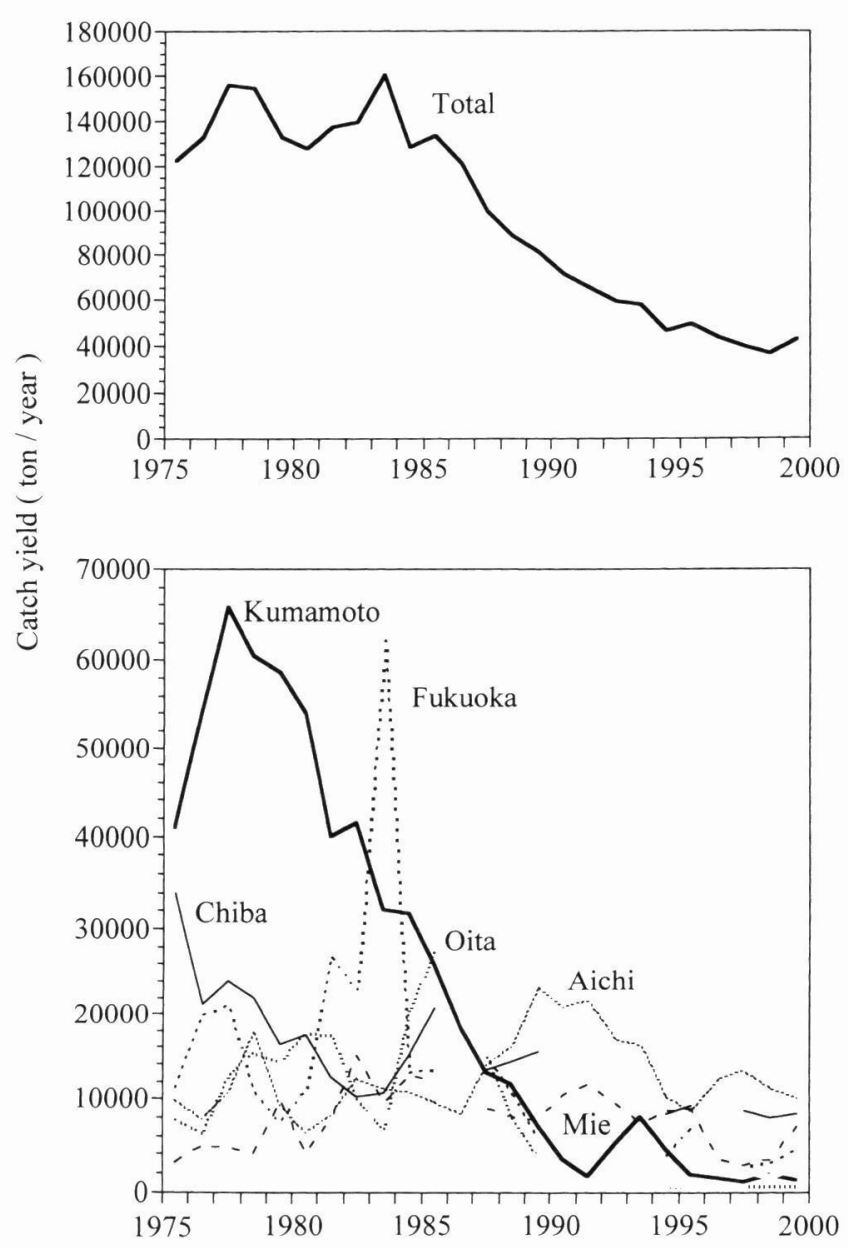

Fig. 1. Ruditapes philippinarum: Variations in annual catch yields in Japan. No data available for interrupted parts of lines.
県の漁獲量の減少傾向を反映している。また，アサリ漁獲 量の多い各県の漁獲量の年変動の傾向には，一定の類似し た傾向を認めがたい．このことは次のことを示唆している． すなわち，上記に言及したように，本邦のアサリの総漁獲 量は近年激減しているが, この激減には, 本邦の主要な県 に共通した要因，本邦のアサリの分布域全体にわたるよう な空間スケールをもつ環境強制的な要因が関与しているの ではなく,もっと小さな空間スケールの, 各水域に固有の 要因が関与しているであろう。

\section{1-2. 有明海のアサリ漁獲量の激減}

\section{1）有明海の環境}

有明海の地形, 底質, 海況, 生物相さらには漁業生産に ついては, 日本全国沿岸海洋誌（日本海洋学会沿岸部会 1985）に詳しくまとめられている。主にこの文献に準拠す れば，有明海の特性は以下のようにまとめることができる。

有明海は 4 県（長崎，佐賀，福岡，熊本）に囲まれ，幅 約 $5 \mathrm{~km}$ の早崎瀬戸によって東シナ海と, また幅約 $200 \mathrm{~m} の$ 本渡瀬戸によって八代海とつながっている (Fig. 2)。 その面 積は約 $1700 \mathrm{~km}^{2}$, 平均水深は約 $20 \mathrm{~m}$, 最深部は湯島海釜 の $165 \mathrm{~m}$ である。流入河川は主に湾奥の福岡県側と湾東の 熊本県側に集中して扔り，そこでは水深が浅く，広大な干 潟が発達している。一方，長崎県側や湾口部においては， 海底の傾斜が急であり，水深も深い，有明海の底質は，広 大な干潟の発達している湾奥や湾東側では泥質もしくは砂 泥質, 長崎県側では砂質もしくは砂泥質, 湾口部では砂碚 質である。有明海では流入河川が湾奥と湾東側に集中して いるために，そこでは河川水の影響が強く，湾口部に比べ

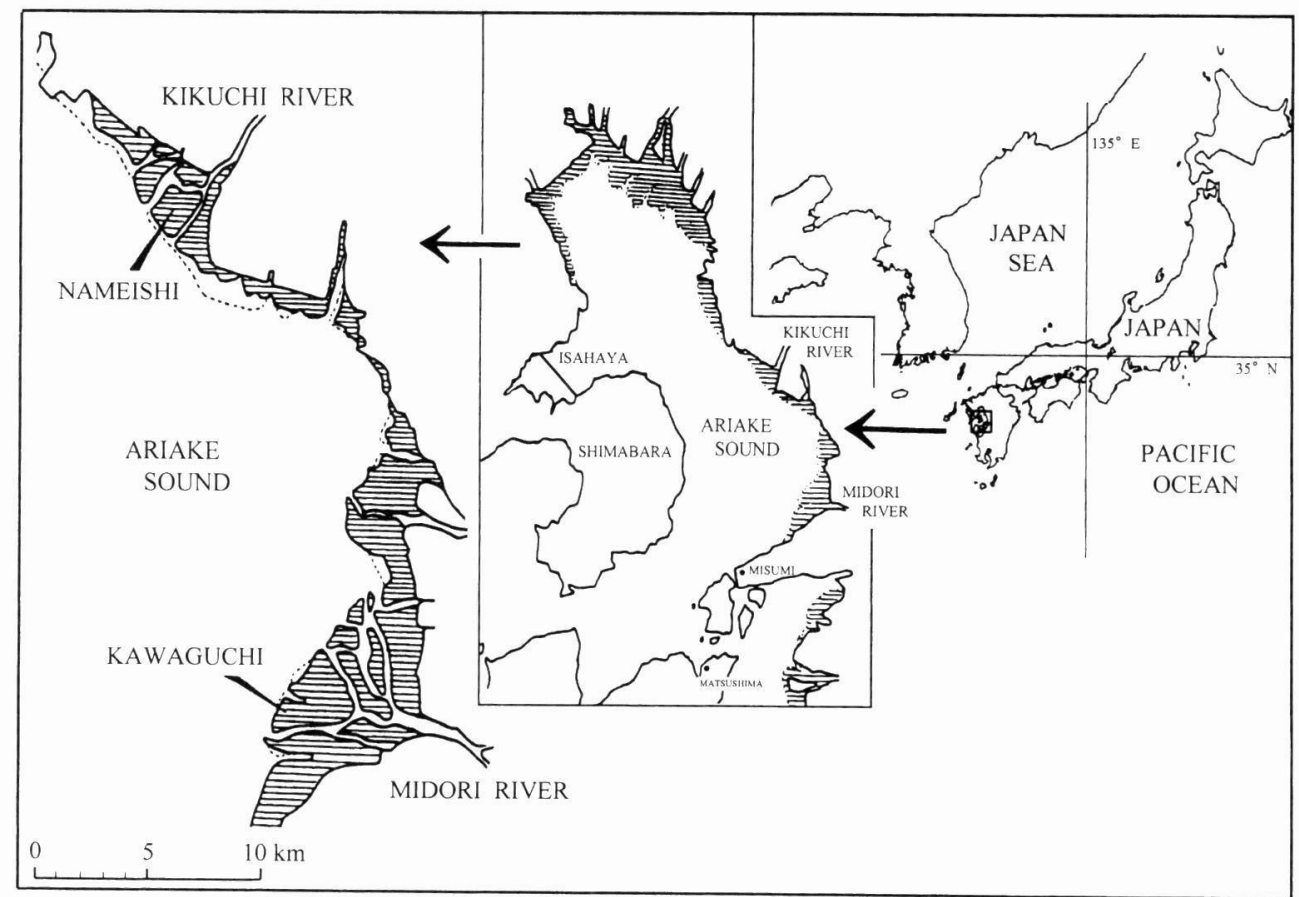

Fig. 2. Study areas (Nameishi, Kawaguchi) in Ariake Sound, southern Japan. Areas with horizontal lines: tidal flats. (After Ishii et al., 2001) 


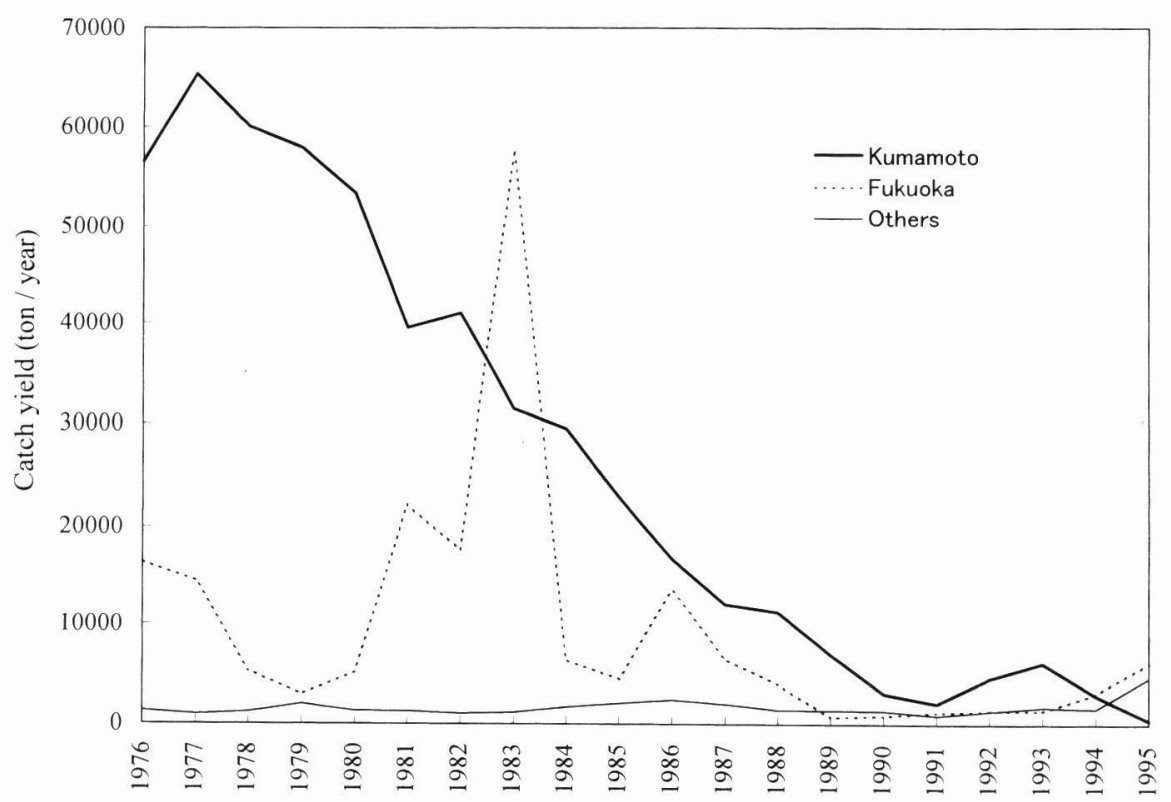

Fig 3. Ruditapes philippinarum: Variations in annual catch yields in Kumamoto, Fukuoka, and other Prefectures bounding Ariake Sound, southern Japan.

て常に塩分は低い。また，有明海はその地形効果のために， 本邦の他の海域に比べて，潮位差が著しく大きく，大潮時 の最大潮位差は湾口部で約 $4 \mathrm{~m}$, 中央部で $5-6 \mathrm{~m}$, 湾奥部 で 6-7 m である。このような大きな潮位差のために，有明 海と外海の間での海水の移出入が激しく, 潮流は上げ潮時 には湾口部から湾奥に向かい，下げ潮時にはこの逆となる。

\section{2) 各県の漁獲量とアサリ漁場}

有明海の中で，水深が浅く，また広大な干潟が発達して いる海域が湾奥の福岡県や湾東側の熊本県にあるために (Fig. 2), 有明海のアサリの漁獲量は主としてこの 2 県に集 中している．福岡県のアサリ漁獲量の突発的な急增が見ら れた 1983 年を別にすれば，1987 年までは熊本県の漁獲量 が福岡県のそれよりも圧倒的に多いが，これ以降，これら 2 県の漁獲量は激減して扔り，しかもそれは熊本県の漁獲 量に顕著であり, 現在では熊本県の漁獲量は福岡県とほほ 同水準かそれよりも低い(Fig. 3). 福岡県と熊本県のアサリ 漁獲量の推移を見る限り, 1987 年とそれ以前では 2 県の漁 獲量の推移には類似した傾向を認めがたいが, 1987 年以降 に抢いてはこれら 2 県の漁獲量の推移には類似した傾向が 認められる。これは, 1987 年以降の漁獲量の激減に，2 県 に共通の，有明海全体の空間スケールの環境強制的な要因 が関与していることを示唆している．熊本県の各漁場での アサリ漁獲量の推移を検討した中原 (1998) は, 共通した要 因として，各漁場での稚貝密度の著しい低下をあげ，その 原因を解明するために幼生加入過程を研究する必要性を強 調している.

\section{2. 有明海のアサリの幼生加入過程と漁場 形成}

\section{2-1. これまでのアサリの研究史一何がわかっていないの か-}

本邦におけるアサリについては，ほぼ 90 年間にわたる 研究の蓄積があり，数え切れないほど多くの研究がある. その研究成果は, 水産打の沿岸漁場整備事業の一環として 出版された「增殖場造成計画指針ヒラメ・アサリ編」(全 国沿岸漁業振興開発協会 1996）にまとめられている。諸 外国も含めて，アサリに関するこれまでの研究成果を概観 するとき，もっとも強く残る印象は，アサリが他の多くの 海産底生無脊椎動物と同様に浮遊期と底生期にまたがった 生活史をもつにもかかわらず，底生期のアサリに研究が集 中していることである.1980 年代の後半に, 三重大学の関 口とそのグループがアサリの幼生加入過程の研究を開始す るまで，本邦においては類似の研究は皆無であったと言っ ても過言ではない。つまり，「浮遊幼生の着底以前と着底 以降の諸過程のいずれが，あるいは加入以前と加入以降の 諸過程のいずれが，漁獲対象となるアサリ資源の形成，規 模，維持あるいは変動を決定しているか」という肝心の問 題に正面から取り組んだ研究は，これまでほとんどない. もち万ん，その理由は，すでに Sekiguchi (1998) や宮脇· 関口 (2000) に詳しく言及されているように, 調査・研究手 法上の多くの困難がつきまとうために, 浮遊幼生に関する 着底拈よび着底以前の諸過程を扱った研究が少ないためで ある。 


\section{2-2. 幼生加入過程とは何か一なぜ幼生加入過程を研究す るのか一}

アサリも含めて, 多くの海産底生無脊椎動物は, 浮遊期 と底生期にまたがった生活史をもつ。これまで, 底生個体 群・群集の構造と機能の主たる維持機構として, 底生期に おける種内・種間関係が主に研究されてきたが，一方にお いて, 個体群 ·群集の形成機構, さらにはその構造と機能 を決定している要因としての浮遊幼生の親・底生個体群へ の加入過程が注目を集めてきた (Underwood \& Denley 1984; Connell 1985). ここでいう幼生加入過程とは, 浮遊幼生の 分散や滞留, 親・底生個体群の生息域への回帰, 着底㧍よ び底生個体群への加入までの一連の過程を含んでおり,こ の分野の研究は「幼生補給 (供給) の生態学 Supply-side ecology」と呼ばれている（宮脇·関口 2000). 海洋生態学 の最近の進展は, 底生個体群·群集の構造と機能, あるい はその動態を解く鍵が, 浮遊幼生の親·底生個体群への加 入過程にあることを示唆している (Roughgarden et al. 1988; Underwood \& Fairweather 1989). この側面の生態学は, 底 生個体群·群集にとってのみ重要なのではなく，ほとんど あらゆる海洋の個体群·群集の研究において, その骨格と 動態を決める要因として追求されている (Mapstone \& Fowlers 1988; Sale 1990).

浮遊幼生の分散と親・底生個体群の生息域への回帰, 浮 遊幼生の摂飭, あるいは浮遊幼生の生残過程等の一連の生 態は, Sekiguchi (1998) や宮脇・関口 (2000) に問題点が整 理されているように, 従来の生物海洋学の分野で十分に研 究可能であろう。しかし, 浮遊幼生の着底過程, さらには 親・底生個体群への加入までの過程, もっと言えば, 浮遊 幼生の生残過程までもが, 底生個体群·群集の動態との絡 みで種々の異なった結果を招来するであろうから，常に底 生個体群・群集の研究と連結させながら, これらの浮遊幼 生の諸問題を追求しなければならないという困難さがある. 海産底生無脊椎動物の幼生加入過程を扱ったこれまでのそ しい研究例からでさえも, 個体群·群集の動態の把握にお ける幼生加入過程の重要性は十分にうかがえる (Roughgarden et al. 1988; Underwood \& Fairweather 1989; Sekiguchi et al. 1995; 宮脇 · 関口 2000; Ishii et al. 2001a).

幸いなことに, ごく最近, 海産動物の個体群・群集の動 態における幼生加入過程の意義を扱った 3 編の優れた総説 が発表された。ひとつは, 軟泥底の底生無脊椎動物の加入 過程を扱った論文であり (Olafsson et al. 1994)，これに干潟 の二枚貝の幼生加入過程を扱った総説論文（宮脇・関口 2000）を加えてもよいであろう．次は岩礁性・サンゴ礁性 の魚類の個体群動態における幼生加入の意義を扱った論文 (Booth \& Brosnan 1995) であり, 他は開放型の海産動物の 個体群・群集の動態と幼生加入の関係を扱った論文 (Caley et al. 1996) である.これらの総説論文はこの分野の必読文 献であると言えるが，その内容は互いに重複せずに多岐に わたっており，ここに要約することは容易ではないので,
ぜひこれらの文献を参照してほしい．これらの総説論文を 踏まえるまでもなく，ここで肝要なことは次のことである. これらの総説論文はいずれも,「幼生加入過程の研究を進 める際に重要なことは, 幼生加入過程に関する知見を集め ることはもちろん大切なことであるが, より重要なことは, 個体群·群集の動態に関与している他の要因（例えば，着 底・加入以降における種内・種間関係あるいは密度依存· 非密度依存的な死亡など）と比較して, 幼生加入過程, 特 に幼生の供給数の制約がどの程度に個体群·群集の動態に 寄与しているかを把握することである」と強調している. 単に浮遊幼生の供給数の変動と底生個体群の動態に相関が あるという結果から，底生個体群の動態に幼生加入過程が 主要な役割を担っていると結論することは, 他の幼生加入 過程, さらには着底・加入以降の諸要因の寄与を無視して いるために，往々にして誤った結論になりやすいので注意 を要する。

\section{2-3. アサリの資源動態における幼生加入過程の意義}

アサリは体外受精であり, 浮遊卵一担輪子幼生 (trochophore)一被面子幼生 (veliger)—変態期幼生 (pediveliger) を経て, 底生期の着底稚貝 (new settler) となる。被面子幼 生は前期の D 型幼生 (D-shaped larvae) と後期の款頂期幼生 (umbo larvae) に区分される。アサリの浮遊幼生は，飼育実 験の結果によれば，水温 $20^{\circ} \mathrm{C}$ では受精後 14-28 日で着底 を始める（鳥羽 1992）。本邦の太平洋側では，アサリの産 卵盛期は水域によって異なっており，東京湾以北では夏に， これ以南では春と秋に産卵盛期があると言われてきた（相良 1981). しかし, Miyawaki \& Sekiguchi $(1999,2000)$ や Ishii et al. (2001b) によれば，東京湾以南では確かにアサリの産 卵盛期は春と秋に認められるが, 浮遊幼生は周年観察され ている.

有明海のアサリの幼生加入過程を扱った唯一の研究であ る Ishii et al. (2001b) に準拠して，この水域のアサリの幼生 加入過程と漁場形成について述べるが，その前に，この研 究で採用されている研究手法の特色について, 用語の定義 も含めて, 詳しく述べる。この研究では, アサリの各成長 段階（款頂期幼生，着底稚貝，小型個体、大型個体）の密 度変動を周年にわたって調べ，款頂期幼生については 2 週 間に 1 回, 水中ポンプで中層の海水 200 リットルを採水し, 着底稚貝と小型個体については 2 週間に 1 回, 底泥を円形 コアー（直径 $34 \mathrm{~mm}$, 深さ $2 \mathrm{~cm}$ ）で採取し，大型個体につ いては 2 週間に 1 回, 底泥を正方形のコドラート $(25 \times 25 \times$ $10 \mathrm{~cm})$ で採取した。各成長段階の定義は Sekiguchi et al. (1995) や Miyawaki \& Sekiguchi (1999, 2000)の場合と同じで あり,「着底稚貝」は殼長 $300 \mu \mathrm{m}$ 未満の稚貝,「小型個体」 は殻長 $300 \mu \mathrm{m}$ 以上から $1000 \mu \mathrm{m}$ 未満の稚貝,「大型個体」 は款長 $1000 \mu \mathrm{m}$ 以上の個体である。また，「加入 Recruitment」は款長が $1000 \mu \mathrm{m}$ 以上に達することと定義している. 殼長以上の個体を「大型個体」と呼び，またこの殼長に達 

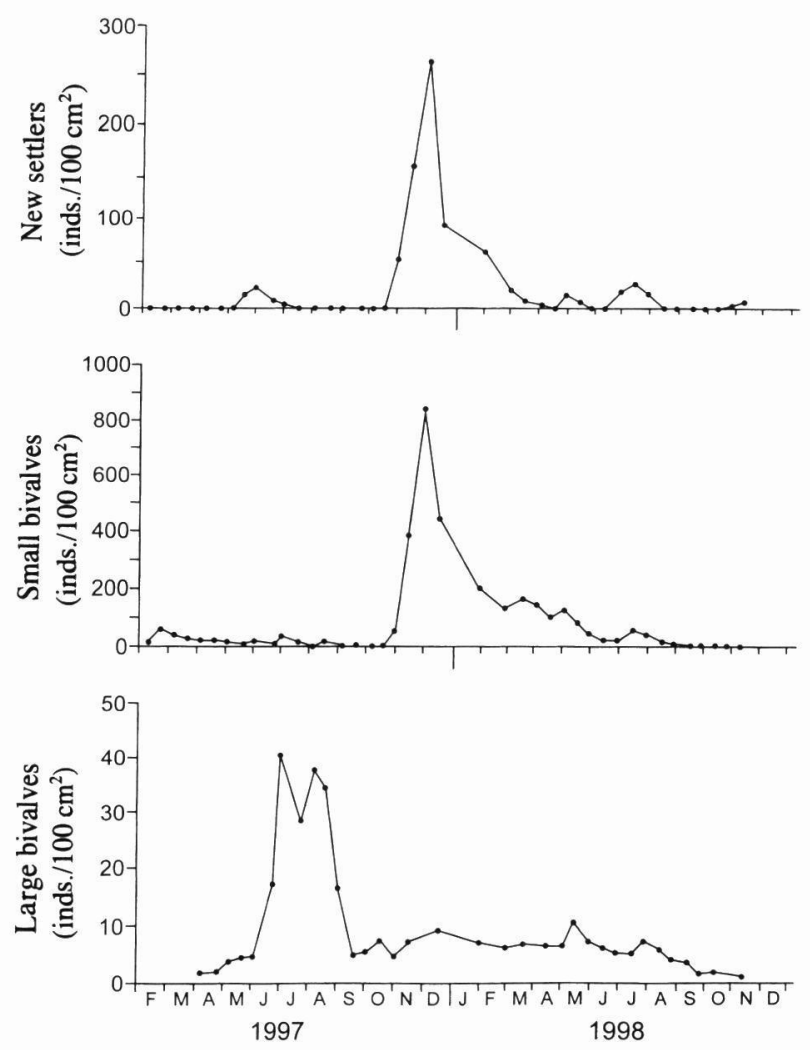

Fig. 4. Ruditapes philippinarum: Seasonal and annual fluctuations of densities of new settlers and small to large individuals at Kawaguchi in Ariake Sound, southern Japan. No data available for December 1998. (After Ishii et al., 2001)

することを「加入」と呼ぶのは奇妙に感じられるであろう が, この定義を採用したのは, 現在までの私達の研究にお いて，この定義が加入過程の把握に有効なためである。も ちろん，この定義は暫定的なものであり，今後の研究の進 展に応じて，より適切な定義に変わるであろう。

調査がおこなわれたのは，菊池川の泥質の河口干潟（滑 石）と緑川の砂泥質の河口干潟（川口）であり，これらは 約 $20 \mathrm{~km}$ 離れている (Fig. 2). これらの干潟は熊本県有数の アサリ漁場であったが，先に述べたように，熊本県のアサ リ漁獲量の激減に伴って, 滑石ではアサリ漁業は壊滅状態 であり，一方川口では細々と漁業が継続されているにすぎ ない.いずれの河口干潟も，かってのアサリ漁業の盛んな 頃と比べれば，泥分が多くなったと指摘されている。

Fig. 4 は川口におけるアサリの各成長段階（浮遊幼生を 除く）の密度変動を示し, Fig. 5 は着底稚貝および小型個 体と大型個体のコホート解析の結果を示している。浮遊幼 生の密度のピークは春一初夏と秋一初冬にあり, 着底稚貝 および小型個体の密度にもこれと対応したピークが認めら れている。しかし，Fig. 4 によれば，着底稚貝と小型個体 のピーク時の密度は秋一冬のほうが圧倒的に高いが, 大型 個体ではこれと逆に，初夏のほうが圧倒的に高くなってお り，初冬に大型個体の密度のピークは認められない。つま
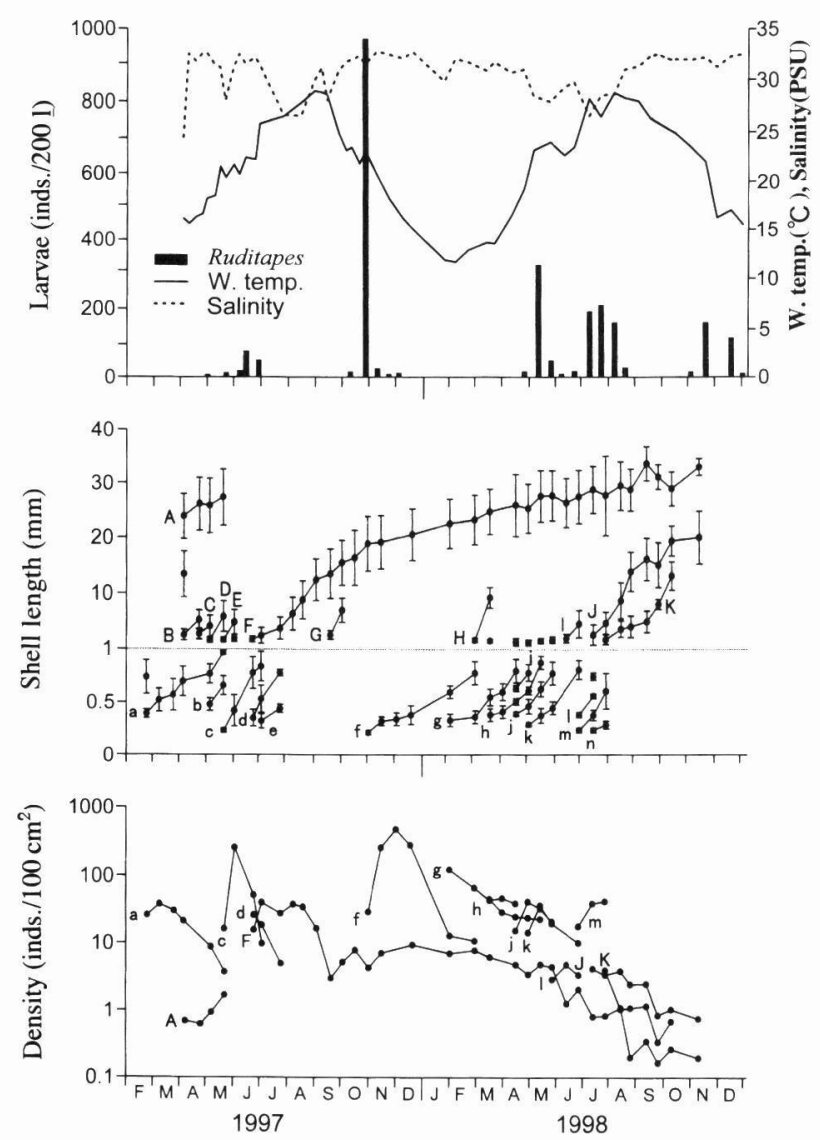

Fig. 5. Ruditapes philippinarum: Seasonal and annual fluctuations of planktonic larval density (upper), and size (middle) and density (lower) of cohorts in the populations at Kawaguchi in Ariake Sound, southern Japan. Solid circles: average shell lengths, vertical bars: standard deviation. No data available for December 1998. (After Ishii et al., 2001)

り, 大型個体の底生個体群の形成に寄与しているのは, 春 一初夏の産卵に由来する浮遊幼生である。ここでは図示し ないが，滑石での調査も同様のことを示している。これら の結果は, 伊勢湾西岸の河口干潟のアサリの幼生加入過程 を扱った Miyawaki \& Sekiguchi (1999, 2000)の結果とは異 なっており，そこではむしろ，秋一初冬の産卵に由来する 浮遊幼生が大型個体の底生個体群の形成に寄与している。

また, 川口のア州の各成長段階の密度は滑石のそれに 比べて高く, 着底稚貝, 小型個体および大型個体の密度が 川口において常に高いのは，そこに供給されている浮遊幼 生の密度が高いことに起因している。つまり, 底生個体群 の規模は第一義的にはそこに供給されている浮遊幼生の密 度によって決定されている。この結果は, 伊勢湾西岸の河 口干潟でおこなわれ, この結果と比較できる唯一の研究成 果である Miyawaki \& Sekiguchi $(1999,2000)$ とは明らかに異 なっている。そこでは, アサリの大型個体の密度は, 着底 稚貝が加入に成功するか否かによって左右されており, 加 入に成功したコホートでは, 着底稚貝と大型個体の密度の 間には統計的に有意な相関関係があるが, 浮遊幼生と着底 稚貝の密度の間には有意な関係は認められていない。結局, 
有明海のアサリ資源においては，供給される浮遊幼生量に よって, 着底稚貝以降の各成長段階の密度がほほ決定され ている. 同じ調査場所，同じ研究手法を用いて研究された ホトトギスガイについても，アサリと同様の結果が得られ ている (Ishii et al. 2001a).

では, 川口に供給されているアサリの浮遊幼生の密度が 滑石のそれよりも高いのは，なぜであろうか. Ishii et al. (2001b)がたどり着いた結論は, 次のようなものであった. 産卵予備軍である大型・親個体の密度が滑石よりも川口に おいて高いことも，その理由のひとつであろうが，それを 考慮してもなお，「川口周辺とその沖において浮遊幼生を 滞留させる海洋物理学的な機構が発達し，それが川口に供 給される浮遊幼生の密度を高めている」と想定せざるをえ ない。同じ調査場所, 同じ研究手法を用いて研究されたホ トトギスガイについても，アサリと同様の結論が得られて いる (Ishii et al. 2001a). この作業仮説の検証のために, 私 たちは熊本県水産研究センターと共同で, 2000 年 6 月に滑 石から川口にかけての浅海水域においてアサリの浮遊幼生 の分布調査を実施した。その結果はすでに第 15 回日本べ ントス学会大会においてロ頭発表されているが, この調査 結果は上記の作業仮説を支持している．現在，これについ て論文を準備中である。また，「どのような海洋物理学的 な機構が川口とその沖での浮遊幼生の滞留に寄与している か」を解明するための調査計画を, 現在, 準備中である.

\section{3. 今後の展開一アサリ漁獲量の激減の 理由を解明できるか一}

有明海でのアサリの幼生加入過程の研究 (Ishii et al. 2001b)によれば，有明海の漁獲対象となるアサリ資源の規 模は，そこに供給される浮遊幼生量によって規定されてい る.この研究成果が過去に溯って適用できるとするならば, 有明海のアサリ漁獲量の増減は浮遊幼生量の増減を反映し ていることになる，次に問うべきは，「なぜ浮遊幼生量の

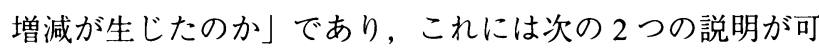
能であろう。ひとつは, 産卵資源量の多鿒と生み出される 浮遊幼生量の間に相関関係があり, 産卵資源量が少ないの で, 浮遊幼生量が少ないという説明である。他は, 産卵量 は多いが, 生み出された浮遊幼生の死亡率が高いために, 供給される浮遊幼生量が少ないという説明である．後者の 考えは事実に反するので，ここでは棄却されるであろう． 前者の考えに立てば，産卵資源量が少ないのは供給される 浮遊幼生量が少ないからであることを考慮すると，「鷄が 先か, 卵が先か」という循環論に陥る。しかし, 海産底生 無脊椎動物は一般に莫大な量の浮遊幼生を生み出し, その 生残率のごく微妙な変動でさえも, 後の成長段階の量に影 響を及ぼすことができるとすれば(Underwood \& Fairweather 1989), アサリ漁獲量の激隇の原因は, 第一義的には浮遊 幼生量の低下をもたらす生残率の低下，これに加えて，乱
獲等による産卵資源量の減少, これらを惹起する環境の悪 化にあると推察できる、今後のアサリ研究の展開としては, 幼生加入過程に焦点を当て，なおかつ全生活史を視野に入 れて, 浮遊幼生の着底以前と着底以降の諸過程が，あるい は加入以前と加入以降の諸過程が，アサリ底生個体群（資 源）の動態に占める相対的な意義を明らかにする必要があ る.

さて，これまでは，「農林水産統計に集計されているア サリ漁獲量の変遷は, 実際のアサリ漁獲量を, 次にこの漁 獲量は資源量の変遷を反映している」との前提のもとで, 検討を進めてきた．本邦の水産資源の中で年間総漁獲量が 数百トン未満のものについては, その漁獲量あるいは資源 量の変動をこれらの資料を使って議論することは適当では ないであろう。しかし, 統計の整備が進んでいる本邦の場 合, 年間総漁獲量が数千トンを超えるアサリ漁獲量の大ま かな変遷の把握には, 問題は少ないと考えられる.

次に問題となるのは, 漁獲量と資源量の関係である。す でに言及したように，熊本県のアサリ漁獲量は 1950 年代 から 1977 年のピーク時までほほ増加を続け, これ以降, 急 速に減少し，現在はピーク時のほほ $1 \%$ に相当する漁獲量 である（中原 1998; Figs. 1, 3). 1977 年以降の漁獲量の激減 に注目が集まっているが，これ以前の漁獲量の急激な増加 傾向と併せ考えると, アサリ漁獲量が 1977 年以降に激減 したのはなぜかという問題は, 1950 年代から 1977 年にか けてアサリ漁獲量が急増したのはなぜかという問題と切り 離せない。このように言えるのは, 漁獲量の変遷が資源量 の変遷を反映している場合であるが, 本邦の沿岸水域のよ うに漁業活動が盛んなところでは，一般に漁獲量の変遷は 資源量の変遷を反映していると考えられている。しかし， 正確に言えば,「1977 年のピーク時までのアサリ漁獲量の 増加が, 単に漁獲努力量の増加に起因するのか, それとも アサリ資源量そのものの増加を反映しているのか」を解明 するには, CPUE（単位努力漁獲量）に基づく漁獲量変動 の解析を必要とする．残念ながら今のところ，そのような データは公表されていないが, 少なくとも, 1977 年以降の アサリ漁獲量の激減はアサリ資源量の激減を反映している と考えても異論はないであろう．末尾ながら英語部分を校 閲していただいた Mark Grygier 博士に深く感謝いたします。

\section{引用文 献}

Booth, D. J. and D. M. Brosnan 1995. The role of recruitment dynamics in rocky shore and coral reef fish communities. Advances in Ecological Research, 26: 309-385.

Caley, M. J., M. H. Carr, M. A. Hixon, T. P. Hughes, G. P. Jones and B. A. Menge 1996. Recruitment and the local dynamics of open marine populations. Annual Review of Ecology and Systematics, 27: 477-500.

Connell, J. H. 1985. The consequences of variation in initial settlement vs. post- settlement mortality in rocky intertidal communities. Journal of Experimental Marine Biology and Ecology, 83: 11-45.

Ishii, R., S. Kawakami, H. Sekiguchi, Y. Nakahara and Y. Jinnai 2001 a. Larval recruitment of the mytilid Musculista senhousia in Ariake 
Sound, southern Japan. Venus, 60: 37-55.

Ishii, R., H. Sekiguchi, Y. Nakahara and Y. Jinnai 2001b. Larval recruitment of the manila clam Ruditapes philippinarum in Ariake Sound, southern Japan. Fisheries Science, 67: 579-591.

Mapstone, B. D. and A. J. Fowkers 1988. Recruitment and the structure of assemblages of fish on coral reefs. Trends in Ecology and Evolution, 3: 72-77.

Miyawaki, D. and H. Sekiguchi 1999. Interannual variation of bivalve populations on temperate tidal flats. Fisheries Science, 65: 817-829.

Miyawaki, D. and H. Sekiguchi 2000. Long-term observations of larval recruitment processes of bivalve assemblages on temperate tidal flats. Benthos Research, 55: 1-16

宮脇 大・関口秀夫 2000. 河口干潟におけるベントスの個体群動 態一幼生の加入過程の視点から. 月刊海洋, 32: 647-653.

中原康智 1998. 熊本県のアサリ資源の現状と問題点. 水産海洋研 究, 62: 117-120.

日本海洋学会沿岸部会 1985. 日本全国沿岸海洋誌, 日本海洋学 会沿岸海洋部会 (編)，東海大学出版会， $1106 \mathrm{pp}$.

Olafsson, E. B., C. B. Peterson and G. A. Ambrose 1994. Does recruitment limitation structure populations and communities of macro-invertebrates in marine soft sediments?: the relative significance of preand post-settlement processes. Oceanography and Marine Biology Annual Review, 32: 65-109.

Roughgarden, J., S. Gaines and H. Possingham 1988. Recruitment dynamics in complex life cycles. Science, 241: 1460-1466.
相良順一郎 1981。アサリ・ハマグリの生理生態. 海洋と生物, 13: $102-105$.

Sale, P. F. 1990. Recruitment of marine species: Is the bandwagon rolling in the right direction? Trends in Ecology and Evolution, 5: 25-27.

Sekiguchi, H. 1998. Sampling strategies vital for making clear dispersal and retention mechanisms of planktonic larvae of benthic invertebrates. In the JSPS Joint Seminar on Marine Science "Marine Conservation and Resource Rehabilitation", Chiangrai, Thailand, pp. $140-151$.

Sekiguchi, H., M. Uchida and A. Sakai 1995. Post-settlement processes determining the features of bivalve assemblages in tidal flats. Benthos Research, 49: 1-14.

鳥羽光晴 1992. アサリ幼生の成長速度と水温の関倸。千葉県水産 試験場研究報告, 50: 17-20.

Underwood, A. J. and E. D. Denley 1984. Paradigms, explanation, and generalizations in models for the structure of intertidal communities on rocky shores. In Strong, D. R., D. Simberloff, L. Abele and A. Thistle (eds.), Ecological Communities, Princeton University press, New Jersey, pp. 151-180.

Underwood, A., J. and P. G. Fairweather 1989. Supply-side ecology and benthic marine assemblages. Trends in Ecology and Evolution, 4: 16-20.

全国沿岸漁業振興開発協会 1996。増殖場造成計画指針ヒラメ・ア サリ編, 全国沿岸漁業振興開発協会 (編), 全国沿岸漁業振興 開発協会, 東京, $316 \mathrm{pp}$. 